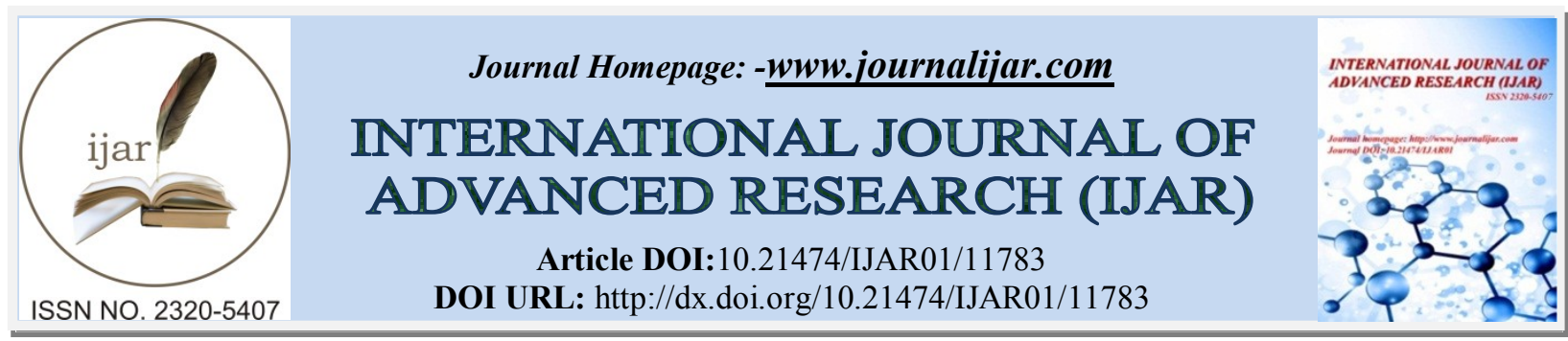

RESEARCH ARTICLE

\title{
ANALYTICAL FRAMEWORK OF POVERTY AND CLIMATE CHANGE
}

\section{Dr. Debesh Bhowmik}

Former Principal, Government of West Bengal, and Honorary Research Professor, Lincoln University College, Malaysia.

\section{Manuscript Info}

Manuscript History

Received: 25 July 2020

Final Accepted: 28 August 2020

Published: September 2020

Key words:

Climate Change, Poverty, Emission,

Forest Policy, Climate Policy,

Sustainable Development

\begin{abstract}
In this paper author studied the nexus between poverty and climate change analytically stating that Nordhaus (2010), Hallegatte (2016) and Jacoby, Rabassa, and Skoufias (2011) models estimated the increase in poverty due to impact of climate change which affect more in disadvantaged people as health shock, food insecurity, unemployment, environmental refugee, and lower income. The paper showed linkages between GHG emission per capita and Gini coefficient, between $\mathrm{CO}_{2}$ emission and productivity and linkages between forest resources, climate change and poverty. The paper also suggested some policy recommendations which were prescribed by international institutions and by the results from the projects. The paper emphasised the speedier implementation of REDD+, LULUCF, forest policies, emission reducing policies and to link MDG with SDG to achieve the Paris Agreement target.
\end{abstract}

Copy Right, IJAR, 2020,. All rights reserved.

\section{Introduction:-}

Paris climate agreement targeted temperature rise of only $1.5^{\circ} \mathrm{C}$ rather than $2^{\circ} \mathrm{C}$ which implies reducing the number of people vulnerable to climate-related risks up to 457 million in which 10 million fewer people would fall in danger due to sea level rise, facing to floods, droughts, and forest fires, would have been disrupted by ecosystems and scarcity of food and livestock, and many of them suffer for water scarcity and about 190 million people would fall into premature deaths over the century.

The World Bank estimated that at $2{ }^{\circ} \mathrm{C}$ of warming, 100-400 million more people could be at risk of hunger and 1-2 billion more people may no longer have adequate water. The global crop yield losses would be 30 percent by 2080 , even with adaptation measures.

It is expected that additional 250,000 people will die per year from malnutrition, malaria, diarrhoea, and heat stress during 2030-2050. The climate change will exacerbate health shocks because poverty-stricken people are uninsured that already create 100 million into poverty every year. It is a real threat that poor people lose their dwellings due to climate change which had displaced140 million people in Sub-Saharan Africa, South Asia, and Latin

America alone. Flood and landslides can weaken degraded infrastructure access andhousing facilities for the people who are living in unplanned or serviced settlements. Presently, 18.8 million people displaced due to disasters in 135 countries - almost twice the numberdisplaced by conflict. Since 2000, the people of poor countries have died from disasters atrates seven times higher than in wealthy countries. The World Bank estimates that withoutimmediate 
action, climate change could push 120 million more people into poverty by 2030 and will rise in subsequent years. Eight hundred million in South Asia alone live in climate hotspots and will see their living conditions decline sharply by 2050 .The poorest half of the world's population which are equivalent to 3.5 billion people produces just 10 percent of carbon emissions, while the richest 10 percent population are responsible for a full half. The wealthiest 1 percent of the world just used 175 times more carbon than the bottom 10 percent of the population of the world.

Balasubramaniam (2018) stated that according to the Food and Agriculture Organization of the UN, the undernourished population was largest in the Central African Republic (47.7\%) followed by Namibia (42.3\%). Consequently, stunting in children is expected to increase in some African communities by $7 \cdot 5 \%$ within 2030 because of climate change. In 2017, Asia constitutes 4.5 billion people which is predicted to grow to 4.8 billion in 2100.And 72437 natural disasters occurred in Asia from 2006 to 2015.The lower-income communities were the worst affected. For example, in 2010,70\% of farmers in Pakistan lost their expected income because of flooding. From 2003 to 2013, Asia's crop and livestock were destructed by climate change amounting to 48billion US\$.

The World Bank estimated that over 90 per cent of the 1.2 billion people have been living in extreme poverty who depend on forests for some part of their livelihoods. Eradicating poverty is therefore impossible without paying specific attention to the 410 million people including 60 million indigenous people, living in the rainforests of Latin America, Southeast Asia and West Africa who live in or near tropical forest areas and depend on these forests for their subsistence and survival needs. In this context it is urgent to link Millennium Development Goal 1 to eradicate extreme poverty and hunger by one half with MDG 7 to ensure environmental sustainability by 2015.

Therefore, the link between the status of biodiversity and the fate of poor people should be a priority in international efforts to ameliorate poverty. However, the fact is that ecosystem services and biodiversity resources are public good which is under-valued in national economies.

Carbon finance initiatives and proposals targeting forest issues are very much required from the view point of three perspectives: climate change mitigation, biodiversity and other environmental contextual issues, and development, particularly for the welfare of the poor. The main thrust of the argument is on how to use forest carbon finance to promote development and secure the welfare of the poor, and the material relating to climate change mitigation and biodiversity is presented largely in support of this concern in line with the social implications of a 'resource perspective'.

Under Clean Development Mechanism the above three flexible mechanisms were available in Kyoto Protocol by which Annex 1 countries are able to meet their emissions reduction targets in non-Annex 1 countries. Reduced emissions from deforestation and forest degradation (REDD) are presently being negotiated under the UNFCCC, and which are likely to include a range of financing mechanisms where voluntary projects are also welcome.

Climate negotiations are not very much responsive towards eradication of poverty in a global level which were mostly allied to climate disasters. The paper seeks to analyse the linkages between poverty alleviation and climate change in a lucid manner.

\section{Literature Review:-}

Jacoby, Rabassa, and Skoufias (2011) showed that there is also significant heterogeneity in the impact of climate on per capita consumption across rural districts of India using household data. It is estimated that increases in mean surface temperature by 2040 could lead to consumption impacts ranging from no change in place to an 11 percent decrease in others. In the case of rural India, the paper estimated that increased mean surface temperature could lead to a 13 percent reduction in agricultural productivity by 2040 (including adaptation). It implies 6 percent decline in average per capita consumption for rural households because households derive more income from their labour endowment.

Stern Review (2007) envisaged that the expected poverty impact will be relatively modest and resulting from continued economic growth and the decline in poverty level will occur over next 40 years which will be concentrated in Africa and South Asia, both of which would see more substantial increases in poverty relative to a baseline without climate change. But, with the climate change scenario, the larger poverty increases would happen although aggregate projected damages are relatively low over the time horizon. The climate change is a general 
phenomenon and it will not disappear in the next century so that the aggregate damages could be substantial and is expected to have a larger effect on poverty.

In a recent study in Brazil, Assunção and Chein (2009) estimated that, on average, agricultural output per hectare fell by 18 percent within 2040 due to the impact of climate change, but the decrease ranged from 40 per cent to 15 per cent in the municipal level. The paper predicted that poverty rate in rural Brazil would increase by 3.2 per cent yet the poor regions would affect more.

AR4 of IPCC (2014) already noted that socially and economically disadvantaged and marginalized people are disproportionally affected by climate change which was also explained by Skoufias (2012) who reminds that the impact of climate change tend to be regressive, falling more heavily on the poor than the rich. Even, it also warns that there is significant variation in the poor regions which were more affected than the prosperous regions specially in context of climate change in Brazil.

The AR5 WGII report concludes that climate change exacerbates inequalities (IPCC, 2014). It notes that socially and geographically disadvantaged people - including people facing discrimination based on gender, age, race, class, caste, indigeneity and disability - are particularly affected negatively by climate hazards. Moreover, exacerbation of inequality can happen through disproportionate erosion of physical, human, and social assets.

Olsson et al.(2014) exemplified that climate change (including climate extremes and variability) affects as a "threat multiplier" for poverty, accelerating the impact of other stressors (including "non-climatic stressors and entrenched structural inequalities"), and leading to increased vulnerabilities. The convergence of multiple stressors and shocks associated with climate change transform people from critical thresholds into to chronic poverty. Climate change and climate variability deteriorated existing poverty, widened inequalities, and triggered both new vulnerabilities and some opportunities for individuals and communities.

The report of State of Food Security in the World emphasised that the number of extreme climate-related disasters, including extreme heat, droughts, floods and storms has increased by two folds compared to early 1990s whose average frequency was 213 events during 1990-2016. It could destroy agricultural productivity contributing to shortfalls in food availability which implied to food price hikes and income losses that decreased people's access to food (FAO et al., 2018). Accordingly, Verner (2010) said that climate change is a concrete threat to poverty reduction which will further exacerbate the vulnerability of the poor.

Robinson (2017) examined the national-level adaptation actions through reviewing of climate adaptation initiatives in 16 SIDS across the Atlantic, Indian Ocean and South China Sea, Caribbean, and Pacific regions. The study found that the various adaptation actions addressed not only climate and climate-induced vulnerabilities, but also nonclimate-induced vulnerabilities. The author found that economic vulnerability (including poverty) was the most commonly reported across all countries among the cases of non-climate-induced vulnerabilities. It is clear that adaptation initiatives are already there in some cases of vulnerabilities to both climate and poverty.

Park et al. (2018) found that poor people are more exposed to high temperature than the average in 37 cases out of 51 countries. The poor people in hotter regions are in warm climate countries and the poorer people are habituated exposed occupations which suggest that a larger vulnerability of poor people to heat extremes and potentially significant distributional and poverty implications of climate change.

Winsemius et al.(2018) studied that poor people are often disproportionally exposed todroughts and floods, particularly in urban areas, but this pattern is far from universal.

In flood distress cases, 34 countries out of the 52 showed a significant result where the half of them exhibited a disproportionally high exposure of poor people to floods. In case of drought,the 30 countries showed significant results where 24 exhibited a disproportionally high exposure of poor people ( 85 per cent in population terms). This result supports the general notion that the relationship between poverty and disaster exposure is a complex one and impacted by multiple factors.

Using a panel data set in Indonesia, Fujii (2016) investigated how climate change can potentially change the vulnerability to poverty. The paper studied on the effect of drought and flood which are the common disasters there 
and found that vulnerability to poverty may increase substantially as a result of climate change in Indonesia after simulation.

Hallegatte et al. (2016) studied that high temperatures will reduce labour productivity of the poorer people who often work outside or without air conditioning. The impact on labour productivity could be large and reduce income by several percentage points so that the relation leads to inverse $U$ shaped.

Bille (2012) stated that the poor rural people generally depend on biodiversity for a wide scale of natural resources and ecosystem services which are mostly essential for their well-being so that they are potentially affected by its degradation. On this assumption, the conservationists, development practitioners and policy makers generally opposed to link biodiversity conservation with poverty reduction.

Palo's (2003) paper aimed to respond to the most essential issues. Taking 35-83 tropical countries covering 70-95 percent of the total tropical forest area the author regressed between income (GDP/capita) and Human Development Index as national poverty measures with relative forest area as a dependant variable, and with population density, Corruption Perception Index and some other independent variables.It was found that the two poverty variables were strongly correlated with the relative forest area. Also, high population density at low income levels enhances forest degradation, deforestation and desertification. The deterioration of forest environment increases poverty, which in turn catapulted population pressure on the remaining forest, and the process moves in a vicious cycle.

Sunderlin (2007) examines poverty and deforestation in developing countries as linkedproblems and focuses on policies that can favour poverty alleviation in forested regions. The paper emphasised on analysis of the spatial coincidence between poverty and forests, and proposed policy options for reducing poverty in forest areas. The paper suggested policies such as (1) the location of the rural poor and types and levels of poverty in relation to forest resources (2) variations in the density of forest cover in relation to distance from urban areas and (3) variations in forest cover over time in relation to a country's forest transition experience and one cannot rely on blindly in economic growth and laissez-faire for reducing poverty in forest areas. The paper concludes that the poorest of the poor people live in high forest areas and are characterised as high rates of poverty.

The paper prescribed policies to lift people out of poverty such as [i] transfer of ownership of forest lands from governments to forest dwellers, [ii] facilitation of access to forest product markets, [iii] promotion of commercialscale community forestry and company-community partnerships and [iv]establishment of payments for forest environmental services that are pro-poor.

Bhowmik(2020) stated that 1.5 billion people would be environmental refugee by 2050 as reported by Sendai Framework for Disaster Risk Reduction and other estimates projected that this figure may be 200-250 million as a result of climate change. Recent estimates suggest that by 2050 , climate change will be able to displace 1 in every 45 people in the world and one in every seven people in Bangladesh. There is no special commitment for the legal needs of the climate -displaced migrants in the Paris Agreement which are broader gaps in rights and funding, and these legal gaps should be rectified. The panellists were on the same opinion that the international community must capitalize on current momentum and political will in favour of climate migration and for policy formulations.

\section{Poverty climate change linkages:}

In linking the long-term climate change impacts on poverty the model of Nordhaus (2010) developed an integrated assessment model i.e. the Regional Integrated Model of Climate and the Economy (RICE) under three scenarios. The first scenario is the baseline which simulates a world without climate change. The second scenario is business as usual which reflects the impact of current trends in economic growth and greenhouse gas emissions (GHGs) on the climate, and the impact of climate change on the overall economy without any emission abatement policies. The third scenario is optimal abatement which is based on Nordhaus's calculation of an emission abatement path, with full participation by all countries, that maximizes global intertemporal economic welfare. Table 1 summarizes the main impacts of climate change on global poverty under these three scenarios. The model projects an annual, global, real per capita output growth rate of 2.2 percent up to 2055 when there is no impact of climate change. The result is that the more than halving the world poverty rate at the $\$ 2$ per day level will be 14.1 percent by 2055 using the growth-poverty elasticities. Under the RICE model's BAU scenario with climate damage, world gross domestic product (GDP) in 2055 would be 1.5 percent lower than in the baseline. In the BAU scenario, the estimated number 
of poor in 2055 would be modestly higher by 10 million, compared to the no climate change scenario where the most of the additional poor would be located in Africa and South Asia.

Table1:- Climate change impact on World Poverty(at $2 \$$ per day).

\begin{tabular}{|l|l|l|l|l|l|l|}
\hline & \multicolumn{3}{|l|}{ Number of poor(million) } & \multicolumn{3}{l|}{ Head count poverty rate(\%) } \\
\hline Scenarios & 2005 & 2055 & change & 2005 & 2055 & change \\
\hline Baseline & 2069.4 & 1259.1 & 810.3 & 32.3 & 14.1 & 18.2 \\
\hline BAU & 2069.4 & 1269.2 & 800.2 & 32.3 & 14.2 & 18.1 \\
\hline Difference from base line & & 10.1 & 10.1 & & 0.12 & 0.12 \\
\hline Optimal abatement & 2069.4 & 1268.5 & 800.9 & 32.3 & 14.2 & 18.1 \\
\hline Difference from BAU & & 0.7 & 0.7 & & 0.01 & 0.01 \\
\hline
\end{tabular}

Source: Skoufias et al.(2011)

Although climate change has significant impact on poverty up to 2030, in the agricultural channel but it remains a secondary driver, as recorded by the nearly 800 million peoplewhich is the difference between the two socioeconomic scenarios in the absence of climate change (Table 1). This does not imply that the impacts of climate change are secondary at the local scale. But the local impact could be massive in some particularly vulnerable places like small islands or in locations affected by large disasters.

Hallegatte (2016) found that the range of possible impacts on poverty remains limited in the prosperityscenario where development not only reduces the impacts but also protects them from the uncertainty. On the other hand, the range of possible outcomes is extremely large where the worst-case estimate increases up to 165 million, and some scenarios showed a decreasein global poverty numbers. The climate change impacts remain moderate in low impact scenario where farmers were benefited the most from higher agricultural prices.

Table 2:- Climate change threatens to worsen poverty(in million).

\begin{tabular}{|c|c|c|c|c|c|}
\hline & \multicolumn{5}{|c|}{ Climate change scenario } \\
\hline & $\begin{array}{ll}\text { No } & \text { climate } \\
\text { change }\end{array}$ & \multicolumn{2}{|c|}{ Low impact scenario } & \multicolumn{2}{|c|}{ High impact scenario } \\
\hline Policy choices & $\begin{array}{l}\text { No of people in } \\
\text { extreme poverty } \\
\text { by } 2030\end{array}$ & \multicolumn{4}{|c|}{ Additional no of people in extreme poverty due to climate change by 2030} \\
\hline Prosperity & 142 & +3 & & +16 & \\
\hline & & Minimum +3 & Maximun+6 & Minimum+16 & Maximun +25 \\
\hline Poverty scenario & 900 & +35 & & +122 & \\
\hline & & Minimum -25 & Maximum +97 & Minimum +33 & Maximum +165 \\
\hline
\end{tabular}

Source- Hallegatte(2016)

The inequality aggravates the conditions of the disadvantaged groups of the society due to impact of climate change in the following three major ways, namely (a) increase in the exposureto climate hazards,(b) increase in the susceptibilityto damage caused by climate hazards, and (c) decrease in the ability to cope with and recover from the damage.

It may be expected that countries with higher inequality will tend to have higher levels of per capita GHG emissions. Some evidences in this regard showed that the correlation between inequality and per capital GHG emissions is at least weakly positive. Inequality thus indeed aggravates climate change. This relation is depicted in the Figure 1. 


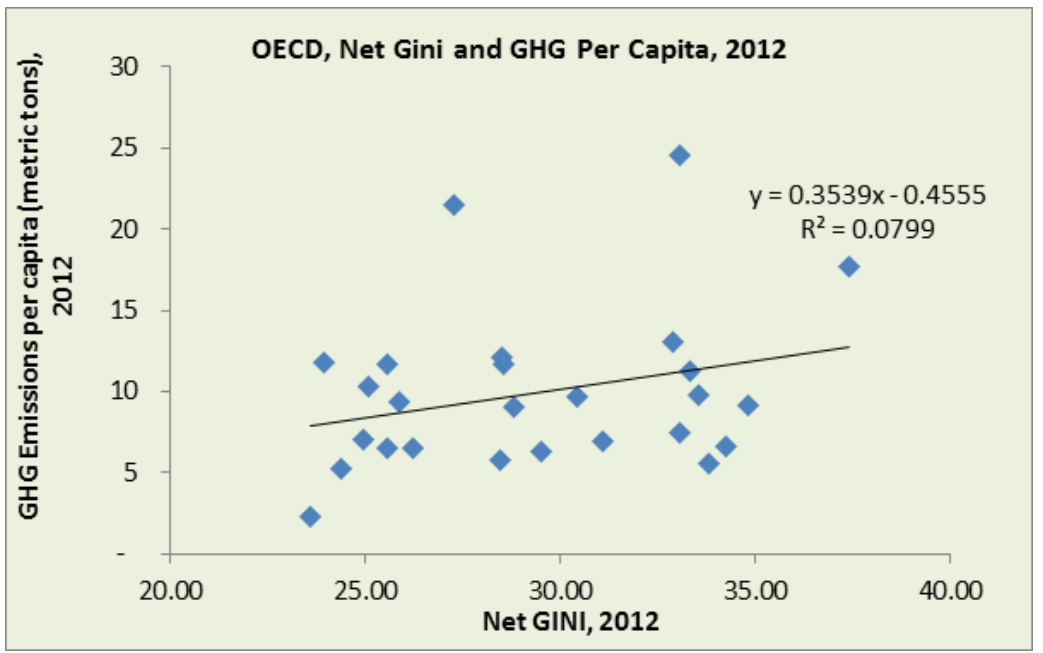

Figure 1:- Positive relationship between inequality and per capita GHG emission among OECD countries.

Source- Hallegatte(2016).

Nexus between Gini Coefficient and $\mathrm{CO}_{2}$ emission per capita in high emitting countries like China, USA, India, France, Russia were positive and insignificant in 2004/2005, and 2010/2011 but the relation is positive and significant in 2015/2016, which implies that the more the emission per capita the more is the inequality. Taking the World Bank data for Gini coefficient and $\mathrm{CO}_{2}$ emission per capita for above countries during 2004/2005,2010/2011, 2015/2016 the estimated double log regression equations are given below.

For 2004/2005

$\log (\mathrm{x})=3.523+0.0525 \log (\mathrm{y})$

$\mathrm{R}^{2}=0.19$

$(28.82) *(0.845)$

For 2010/2011

$\log (\mathrm{x})=3.526+0.0617 \log (\mathrm{y})$

$\mathrm{R}^{2}=0.357$

$(35.8) *(1.29)$

For 2015/2016

$\log (\mathrm{x})=3.246+0.18002 \log (\mathrm{y})$

$(24.21)^{*}(2.96)^{*}$

$\mathrm{R}^{2}=0.81$ (significant at $10 \%$ level), where $\mathrm{x}=$ Gini coefficient, $\mathrm{y}=\mathrm{CO}_{2}$ emission per capita. ${ }^{*}=$ significant at $10 \%$ level.

The disadvantaged sections of the people are more sufferer to climate damages due to lack of diversification of their assets. For example, housing stock is considered as saving of urban poor in times of flood and livestock is treated as savings for rural poor in times of drought.

No doubt the wealthier households are less susceptible to damage caused by climate hazards because they can diversify their assets both spatially and financially. The disadvantaged groups suffered much from health effects as a result of climate change. They suffered in both short run and long run. They suffer from loss of productivity, employment and income in the short run and they suffer from loss of human capital in the long run.

Thus, low-income countries in general are more exposed to the adverse effects of climate change which can worsen the relative position and can aggravate inequality across the countries. Also, the climate change reinforcing (feedback) effect is true for cross-country inequality.

Bullard (2015) stated that the number of impoverished people will grow from the current 702 million to around 900 million by 2030 without factoring in climate change. When climate change is part of the equation, more than a billion people will be in poverty. Most of that additional 100 million, the report says, will become poor due to rising food prices. The estimate observed that the people in extreme poverty without climate change is about 142 million which increased to 158 million with the impact of climate change whereas 900 million poverty stricken 
people belongs to without climate change instead of 1026 million poverty stricken people with the impact of climate change where 70 million emerged from agriculture, 28 million from health factor and 19 million from fall of labour productivity.

World Economic Forum (2019) confirmed that climate change is exacerbating hunger in some of the world's poorest countries. And those most at risk are the least to blame. The report of Christian Aid on the impact of climate change on global food security assured that the hungriest countries contribute the least to global warming. It is fully supported by the climate and food vulnerability index which claimed that the 10 most food insecure nations in the world generate just 0.08 per cent of the global carbon emissions. This is exemplified by the Table 3 which clarified that as the planet warms, agriculture and food supplies are being disrupted, which is disproportionately impacting underdeveloped countries.

Burundi, which tops Christian Aid's food-insecurity (Table3), is highly dependent on small-scale agriculture, which employs around $90 \%$ of its workforce. The farmers' vulnerability is increasing in numbers which are caused by extreme weather, drought and flood in course of climate change.

Table3: Climate and Food vulnerability index

\begin{tabular}{|l|l|l|l|l|}
\hline $\begin{array}{l}\text { Climate and Food } \\
\text { vulnerability index } \\
\text { rank }\end{array}$ & country & $\begin{array}{l}\text { Food insecurity } \\
\text { score }\end{array}$ & $\begin{array}{l}\mathrm{CO}_{2} \text { emission per } \\
\text { capita (in tonne) }\end{array}$ & $\begin{array}{l}\mathrm{CO}_{2} \text { emission per } \\
\text { capita rank (out of } \\
113 \text { ) }\end{array}$ \\
\hline 1 & Burundi & 23.9 & 0.027 & 113 \\
\hline 2 & Congo & 26.1 & 0.043 & 112 \\
\hline 3 & Madagascar & 27 & 0.163 & 104 \\
\hline 4 & Yemen & 28.5 & 0.443 & 90 \\
\hline 5 & Sierra Leone & 29.2 & 0.173 & 103 \\
\hline 6 & Chad & 31.5 & 0.062 & 110 \\
\hline 7 & Malawi & 32.4 & 0.084 & 109 \\
\hline 8 & Haiti & 33 & 0.321 & 96 \\
\hline 9 & Niger & 33.7 & 0.116 & 107 \\
\hline 10 & Zambia & 33.7 & 0.29 & 97 \\
\hline
\end{tabular}

Source-World Economic Forum (2019).

According to Christian Aid, the African nation's economy produced just 0.027 tonnes of $\mathrm{CO}_{2}$ per person which is the smallest, on the contrary, the emissions generated by a single US citizen are equal to 581 people in Burundi.

Hubacek et al. (2017) explained that in 2013,770 million people lived below the poverty line of $1.90 \$$ per day (PPP) and $50 \%$ of world population lived below poverty line of 2.97 \$ per day (PPP).Top $10 \%$ of income earners are responsible for $36 \%$ of global carbon emission whereas 836 million or $12 \%$ of global extreme poverty stricken people contribute only $4 \%$ of global emission or bottom $50 \%$ contribute about 13 per cent emission. Based on this scenario, to lift the population above the poverty line $\left(2.97 \$\right.$ per day on PPP) as per IPCC estimated another $0.6^{\circ} \mathrm{C}$ will be added by this century. This is ambitious target which is required a greater life style and behavioural changes emerging with huge global carbon inequality towards a low carbon society. This target of eradicating extreme poverty should be increased by $2.8 \%$ which would require an increase of mitigation rate by $27 \%$.

\section{Forest, climate change and poverty:}

The forests contribute us fresh water and clean air as well as fertilize the soil to grow food, energy and biomass. Forests are considered as a major carbon sink that mitigates climate change. On the other hand, forests are the source of life and play as an important role in the preservation of our fragile environment. Tisdell (2012) stated that natural forests contribute to economic sustainability through [i] their role as carbon sinks and store,[ii]their favourable impacts on local climates,[iii]their conservation of genetic diversity,[iv] their supply of hydrologic services of value regionally,[v] their role in reducing rates of soil erosion and generates positive externalities such as less silting of dams and forests and avoidance of reduced fish population.

Natural forests are a renewable resource and can be used to a limited extent by humans for competitive purposes without significantly eroding their provision of other valuable ecosystem services. Sometimes natural forests 
provide valuable social safety nets for local communities and satisfy the needs of the poor and provide employment opportunities.

47 million people work in forestry industries globally .People generally benefitted from forests and trees to get [i]Subsistence goods such as fuelwood, medicines, wood for building, rope, bushmeat, fodder, mushrooms, honey, edible leaves, roots, fruits [ii] Goods for sale all of the above goods, arts and crafts, timber and other wood products [iii] Indirect benefits such as land for other uses, social and spiritual sites, environmental services, including watershed protection and biodiversity conservation,[iv] Biodiversity of trees and crops in the managed forest/agricultural landscape can often be more important to poor people than those in protected areas.

The $4^{\text {th }}$ assessment report of IPCC(2007) estimated that under business as usual the emission of GHG was projected to rise by $25-90 \%$ during $2000-2030$. So the target is to decarbonise economic activities to reduce $\mathrm{CO}_{2}$ equivalent by $50 \%$ within 2050.It implies that the rate of decarbonisation needs to be between 0.5-2.5 per cent per year. The role of forest is extremely significant in the sense that not only the above-mentioned emission could be avoided through reduction of deforestation but also at the same time the complementary action of afforestation could play a significant role.

In the 13th session of the conference of the parties (COP 13) in Bali, countries decided to launch demonstration activities aiming at reducing emissions from deforestation and forest degradation in developing countries (REDD) followed by a performance-based mechanism was adopted in Cancun (COP 16).It will compensate developing countries in reducing emissions from deforestation and forest degradation or increase carbon absorptions through carbon stock enhancement, sustainable management of forests and forest conservation (REDD+). Even, the Warsaw Framework consolidates REDD+ as one of the key policy options in the climate change mitigation toolbox and 2015 Paris Agreement mentioned REDD+ explicitly as a component.

The Cancun Agreement mentioned safeguard measures including respect for the knowledge and rights of indigenous people and full and effective participation of indigenous peoples and local communities and the enhancement of social benefits considering the need for sustainable livelihoods of indigenous peoples and local communities. It will monitor in unfolding REDD+ activities in developing countries. Although REDD+ brings a whole new set of challenges and access to benefits in the form of carbon payments but the policy has no guarantee of equitable distribution.

Community Forest Management is seen as an option to protect the forest, as well as meeting social goals. It is more successful in forest conservation, sustainable management of forest which results in reduced rates of degradation, and enhancing carbon stock, than in reducing deforestation. Community Forest Management is able to combat deforestation but several other exogenous factors which are related to the governance and control of communities.

Community Forest Management contributes to poverty alleviation in terms of social benefits since sustainable forest management cannot be achieved in isolation. A government can maximize the contributions of forestry to poverty reduction through wider strategies for economic and social development through[i] empowering forest-dependent people, [ii] building entrepreneurial skills, [iii] improving governance, and fight corruption. Good governance in forestry is central strategy to fight against poverty. It should be included as a central part of national forest programmes since it is integrated into poverty reduction strategies.

FAO (2008) explained that in poverty reduction strategies, trees, woodlands and forests are generally meeting basic needs for wood, fuel, medicine, fruits and other food, generating employment and contributing to economic growth, providing fodder for livestock, regulating the quality and supply of water, and offering a range of ecological services. To increase potentiality of poverty reduction from forest resources, halting deforestation, rehabilitating degraded land, combating desertification, improving productivity and value addition, involving communities in management, strengthening enforcement, and introducing incentives for private sector participation must be implemented through governance.

Bhowmik (2018) studied that more than 350 million indigenous people who generally protect forests, forest products, ecosystem and biodiversity of forests during decades of generations living into the forests' premises, are being removed from their lands and dwellings in order to revive protected area and conservation of national forest. Their lives and lands are being destroyed by conservation of industry, tourism and big business through 
multinationals. The evidence proved that tribal people are better at looking after their environment than anyone else. The findings of the Centre for International Forestry Research and the World Bank claimed that when traditional communities are given full legal rights to their land, they can protect the environment efficiently and chiefly. The irony is that anti-people conservation does not appear to having a beneficial effect on wildlife and forest resources and may in fact be self-defeating. The worldwide protest of tribes through international summit established their rights of land and properties which can throw light to introduce new forest policy in reducing emissions.

\section{Policy considerations:}

To maintain global warming target, especially to ameliorate global poverty so as to counteract climate change impacts, the following policies are important and desirable.

[i]LULUCF targets should be presented and accounted for separate agendafor action.

[ii]REDD is modelled as a largescale Payment for Ecosystem Services (PES) scheme where countries are paid according to quantified amounts of avoided emissions considering as a win-win solution for countries in both the global South and North.

[iii]According to an estimate, climate change could drag more than 100 million peopleinto poverty by 2030 which can be reduced to fewer than 20 million, if rapid, inclusive, and climate-informed development is combined with targeted adaptation actions.

[iv]In protecting climate change shocks, financial inclusion, insurance, social safety nets, and remittances are important.

[v]Universal health coverage would contribute greatly to climate change adaptation and monitoring and surveillance systems.

[vi]In the poorest countries, the support from the international community to offset possible trade-offs between poverty reduction and climate change mitigation is welcome.

[vii]In the short run, rapid, inclusive, and climate-informed development can prevent most (but not all) consequences of climate change on poverty.

[viii] Immediate mitigation is required to remove the long-term threat that climate change creates for poverty eradication.

[ix][a] Review existing poverty alleviation policy in the light of climate change and adjust them according to the specific manifestations of climate change in ecologically fragile areas.

[b]Build the resilience of poor communities to climate-related natural disasters.

[c]Make climate change adaptation a priority in international negotiations.

[d]Moderate uncontrolled development and continue to promote the improvement ofpoor infrastructure.

[x]Good governance, human resources, institutional structures, public finance, and natural resource management can strengthen adaptation mechanism.

[xi]Relate the policies between

1. Pro-poor climate mitigation and adaptation

2. Climate-sensitive poverty reduction and food security initiatives

3. Cross-cutting and sectoral synergies

4. Coherence and coordination within and among institutions

5. Strengthening and supporting local initiatives

[xii]Adaptive Social Protection (ASP) approaches help communities to anticipate, absorb and adapt to climate risk, through solutions like:

1. cash transfers before and after climatic disasters,

2. subsidies to enhance food and water security for affected communities, 
3. employment-generating programmes around climate resilient infrastructure,

4. use of weather indexed insurance for farmers, and

5. Systems to facilitate mobility and effective resettlement for climate affected communities.

[xiii]Community Forest Management is a good policy which reduces deforestation and forest degradation, conserving forests, sustainably manage forests and enhance forest carbon stocks and generates social benefits including on income, employment, security, empowerment and equity at the local level.

[xiv]Rewarding Upland Poor for Environmental Services (RUPES)should be implemented since it is successful in Asian countries.

[xv] Pro-poor policy can be implemented successfully through providing more access to forest product markets, promoting of commercial-scale community forestry and company-community partnerships, and establishing of payments for forest environmental services.

[xvi] Global Forest Policy requires the co-ordination of policies adopted by the multilateral autonomous international institutions namely,[a]United Nations Conference on Environment and Development,[b]Intergovernmental Panel on Forest,[c] Inter-governmental Forum on Forest,[d] United Nations Forum on Forest,[e] Committee on Forestry,[f] Food and Agricultural Organisation, and [g] International Tropical Timber Organisation.

\section{Conclusions And Remarks:-}

The paper analytically examined the linkages between climate change and poverty and concluded that Regional Integrated Model of Climate and Economy of Nordhaus(2010) suggested that poverty stricken people ( \$2 per day) will increase by $14.1 \%$ within 2055 and Hallegatte model(2016) with highest impact scenario of climate change projected an increase of 122 million poverty by 2030.The nexus between GHG emission per capita and Gini coefficient among top five emitting countries like China, USA, India, Russia and France during 2004/05 and 2010/11 were found positive and insignificant but it was positive and significant at 10\% level in 2015/16. Even,the relation between $\mathrm{CO}_{2}$ emission and productivity is inverse $\mathrm{U}$ shaped. The disadvantaged people suffered much more from climate change impacts from health shock, food insecurity, unemployment and lower income which were also recognised by IPCC (2014). Even, the vulnerable people turned to be environmental refugee or climate refugee through the impact of natural disaster. Achieving target of Paris agreement, IPCC estimated another $0.6^{\circ} \mathrm{C}$ would be added to lift global people above poverty line of $2.97 \$$ per day and eradicating extreme poverty should be increased by $2.8 \%$ which will require a rise in mitigation rate by $27 \%$ which demands a rapid change of global lifestyle. This implies that fulfilment of target of REDD+, LULUCF, climate policy targets should be more effective and speedier as well as national and international forest policy should be amalgamated along with global institutions and climate finance must be pro-poor. Protection and conservation of forest policy must be designed for poverty alleviating programme with the inclusion of interest and environmental activities of tribal people. The steady and successful implementation of sustainable development goal 13 should be linked with Millennium Development Goal one and seven through all national governments.

\section{References:-}

1. Assunção, J., \& Chein Feres, F. (2009). Climate Change, Agricultural Productivity, and Poverty. (Working Paper), Department of Economics, PUC-Rio de Janeiro, Brazil.

2. Balasubramanian, Muniyandi. (2018, October).Climate change, famine, and low-income communities challenge Sustainable Development Goals. Planetary Health, 2, Institute of Social and Economic Change, Bengaluru. Retrieved from www.thelancet.com > article > PIIS2542-5196(18)30212-2

3. Bhowmik, Debesh. (2012). Issues on Forest Management and Climate Change. In Raj Kumar Sen (Ed.), Forest Management and Sustainable Development(pp70-88), New Delhi: Deep and Deep Publications Pvt. Ltd.

4. Bhowmik, Debesh. (2018). Survival of Indigenous People: Environment Protection and Conservation. In Debesh Bhowmik (Ed.), Developmental Issues of Tribes. (pp143-160), New Delhi: Shandilya Publications.

5. Bhowmik, Debesh. (2020). Problems of Refugee and the Climate Change. In Sourav Kumar Das and Nidhi Choudhury (Eds.), Refugee Crises and Third-World Economies. (pp 45-72).New Delhi: Emerald Publishing Limited. doi:10.1108/978-1-83982-190-520201008

6. Billé, Raphael., Lapeyre, Renaud., \&Pirard, Romain. (2012). Biodiversity conservation and poverty alleviation: A way out of the deadlock? Sapiens,5(1). Retrieved from https://journals.openedition.org/sapiens/1452 
7. Boyce, James K. (1994). Inequality as a Cause of Environmental Degradation. Ecological Economics, 11(9), 169-178. Retrieved from https://doi.org/10.1016/0921-8009(94)90198-8

8. Boyce, James K. (2003). Inequality and Environmental Protection. Political Economy Research Institute (PERI). (Working Paper no. 52). Amherst, MA: University of Massachusetts. Retrieved from https://scholarworks.umass.edu/peri_workingpapers/59/.

9. Bullard, Gabe. (2015, December 1). National Geographics by Daisy Chung. https://www.nationalgeographic.com/news/2015/12/151201-datapoints-climate-change-poverty-agriculture/

10. FAO. (2008). Links between National Forest Programmes and Poverty Reduction Strategies, by R. McConnell. (Forestry Policy and Institutions Working Paper No. 22). Rome.Retrieved from http://www.fao.org/docrep/pdf/011/k3730e/k3730e.pdf

11. FAO, IFAD, UNICEF, WFP \& WHO. (2018). The State of Food Security and Nutrition in the World 2018. Building climate resilience for food security and nutrition. Rome, FAO. 181 pp. Retrieved from www.fao.org/3/I9553EN/i9553en.pdf.

12. Fujii, T. (2016). Climate Change and Vulnerability to Poverty: An Empirical Investigation in Rural Indonesia. (ADBI Working Paper 622). Tokyo: Asian Development Bank Institute. Available: https://www.adb.org/publications/climate-change-vulnerability-poverty-indonesia

13. Georgeson, Lucien., Maslin, Mark., Poessinouw, Martyn., \&Howard, Steve. (2016, February). Adaptation responses to climate change differ between global megacities. Nature Climate Change, 6(6),1-6. DOI: $10.1038 /$ nclimate2944

14. Hallegatte, S. et al. (2016). Shock Waves: Managing the impacts of climate change on poverty. Climate change and development series. (Climate Change and Development Series). Washington, DC, World Bank. Retrieved from https://openknowledge.worldbank.org/handle/10986/22787).

15. Hubacek, K., Baiocchi, G., Feng, K., \& Patwardhen, A. (2017, October). Poverty eradication in a carbon constrained world. Retrieved from doi:10.1038/s41467-017-00919-4

16. IPCC. (2007). Climate Change 2007: Impacts, Adaptation and Vulnerability. (Fourth Assessment Report). Retrieved from https://www.ipcc.ch

17. IPCC. (2014). Climate Change 2014: Impacts, Adaptation and Vulnerability. New York: Cambridge University Press.

18. Jacoby H., Rabassa, M., \& Skoufias, E. (2011, April). Distributional Implications of Climate Change in India. (Policy Research Working Paper 5623), World Bank, Washington, DC. Retrieved from https://www.researchgate.net/publication/228119131_Distributional_Implications_of_Climate_Change_in_Indi a

19. Nordhaus, W. (2010). Economic Aspects of Global Warming in a Post-CopenhagenEnvironment. Proceedings of the National Academy of Science,107 (26),11721-26. Retrieved from https://doi.org/10.1073/pnas.1005985107

20. Olivieri, S., Rabassa, M., \& Skoufias, E. (2010). Potential Impacts of Climate Change on Poverty: An Analysis Based on RICE 2010 Predictions. Unpublished manuscript, PRMPR, World Bank, Washington, DC.

21. Olsson, L. et al. (2014). Livelihoods and poverty.In C.B. Field (Eds.),Climate Change 2014: Impacts, Adaptation, and Vulnerability. Part A: Global and Sectoral Aspects, pp. 793-832. Contribution of Working Group II to the Fifth Assessment Report of the Intergovernmental Panel on Climate Change. Cambridge, UK, Cambridge University Press. (also available at www.ipcc.ch/site/assets/uploads/2018/02/WGIIAR5Chap13_FINAL.pdf).

22. Palo, Matti. (2003, August). Poverty reduction by tropical forests: rhetoric or viable option? In Sim, H.C et al. (Eds.), Forests for poverty reduction: Opportunities with Clean Development Mechanism, Environmental Services and Biodiversity. (pp7-24). Seol: Rap Publication.Retrieved from http://www.fao.org/3/a-ae537e.pdf.

23. Park, J., Bangalore, M., Hallegatte, S., \& Sandhoefner, E. (2018). Households and heat stress: estimating the distributional consequences of climate change. Environment and Development Economics,23(3). Available at DOI: $10.1017 / \mathrm{S} 1355770 \mathrm{X} 1800013 \mathrm{X}$

24. Robinson, S.A. (2017). Mainstreaming climate change adaptation in Small Island Developing States. Climate and Development, 11(1), 47-59. Retrieved from https://doi.org/10.1080/17565529. 2017. 1410086.

25. Roy, J., et al. (2018). Sustainable Development, Poverty Eradication and Reducing Inequalities. In V. MassonDelmotte. (Eds.), Global warming of $1.5^{\circ} \mathrm{C}$. (An IPCC Special Report on the impacts of global warming of $1.5^{\circ} \mathrm{C}$ above pre-industrial levels andrelated global greenhouse gas emission pathways, in the context of strengthening the global response to the threat of climate change, sustainable development, and efforts to eradicate poverty), (pp.445-538). Geneva, World Meteorological Organization.Retrieved from https://www.ipcc.ch/site/assets/uploads/sites/2/2019/05/SR15_Chapter5_Low_Res.pdf 
26. Skoufias, Emmanuel. (Ed.). (2012). The Poverty and Welfare Impacts of Climate Change: Quantifying the Effects, Identifying the Adaptation Strategies. Washington, D.C.: World Bank. Retrieved from https://openknowledge.worldbank.org/bitstream/handle/10986/9384/714510PUB097800C0disclosed070250120 .pdf? sequence $=1$

27. Stern, N. (2007). The Economics of Climate Change: The Stern Review. Cambridge.UK: Cambridge University Press.Available at https://doi.org/10.1017/CBO9780511817434

28. Sunderlin, W.D. (2007). Poverty and forests: multi-country analysis of spatial association and proposed policy solutions. Sonya Dewi and Atie Puntodewo. Bogor, Indonesia: CIFORRetrieved from https://www.cifor.org/publications/pdf_files/OccPapers/OP-47.pdf

29. Tisdell, C. A. (2012). Managing Forests for Sustainable Economic Development: Optimal Use and Conservation of Forests. In Raj Kumar Sen (Ed.), Forest Management and Sustainable Development(pp3-16), New Delhi: Deep and Deep Publications Pvt. Ltd.View at https://espace.library.uq.edu.au/view/UQ:303261

30. UNDP. (2018). Climate Change and the Rise of Poverty.Retrieved from https://www.undp.org/content/undp/en/home/blog/2018/Climate_Change_and the_Rise_of_Poverty.html

31. Verner, D. (Ed.) (2010). Reducing Poverty, Protecting Livelihoods, and Building Assets in a Changing Climate: Social Implications of Climate Change in Latin America and the Caribbean. Washington, DC, World Bank. Retrieved from https://openknowledge.worldbank.org/handle/10986/2473).

32. Winsemius, H.C., Jongman, B., Veldkamp, T.I.E., Hallegatte, S., Bangalore, M., \& Ward, P.J.(2018). Disaster risk, climate change, and poverty: assessing the global exposure of poor people to floods and droughts. Environment and Development Economics, 23(3). Available at https://doi.org/10.1017/S1355770X17000444

33. World Economic Forum (2019, August 13). Climate change is exacerbating hunger in some of the world's poorest countries. And those most at risk are the least to blame. Available at www.weforum.org/agenda/2019/08/climatechange-is-causing-hunger-in-some-of-the-worlds-poorest-countries-and-those-most-at-risk-are-the-least-toblame/. 